\title{
The Kuwaiti Constitutional Court and its Role in Protecting the Fundamental Liberties
}

\section{Fawaz Almutairi}

\begin{abstract}
The chapter relates to the Kuwaiti constitutional judiciary and deals with the issue of how the cases reach the court, and the most important legislations governing the court's formation and works. The chapter also analyzes some cases that dealt with the issue of Islamic law and its impact, whether directly or indirectly, on women in the rulings of the Constitutional Court of Kuwait. We will address some cases that were brought before the court because they contained legislation that affect women's rights in different aspects, whether their political right, or their right to be treated equally, or their right to free movement. The chapter finds how the constitutional court faced such challenges by providing pro-women interpretations through reconciling the Islamic law with the constitutional principles.
\end{abstract}

\section{Introduction}

The Constitutional Court has been endowed with a developed degree of monitoring and control over laws, bylaws and regulations that violate fundamental rights, including the right to equality, the right to litigation, the right to assemble and gather, and other constitutional and fundamental rights. The Constitutional Court, in its early stages, was rarely rendering decisions of unconstitutionality even if a violation of constitutional provisions by the legislation in question was evident. This may be due to a misconception by some of its members of the role played by the Constitutional Court, or to the fact that the majority of the members of the court are graduates of the Faculty of Sharia, whose views of basic rights differs from their colleagues that graduated from the Faculty of Law. With fierce criticism directed to the Constitutional Court on this matter, the court successively issued decisions that declared some laws or regulatory provisions unconstitutional. Especially in the period from 2006 to 2009, the Court took course to confront legislation contrary to the Constitution 
and began to take its natural place to address such violating legislation as the protector of constitutional provisions against infringement.

\section{Procedures of filing constitutional motions concerning fundamental liberties}

The jurisdiction of the Constitutional Court - the scope of authority and competences to hear cases and interpret the constitution - enables it to review a wide range of constitutional motions or complaints. It carries out the process of examining questions of constitutionality as an inherent competence wherein it examines constitutionality of laws, decree-laws and regulations.

International treaties have the binding force of ordinary law whether, similar to what applies for Egypt. With regard to Kuwait, it is established by Article 70 of the Constitution ${ }^{1}$. This poses the question of what will happen if there is a conflict between a law and an international treaty. In Egypt, the constitutional court considered that the law is repealed and gave preference to the treaties in its ruling issued on March 18, 1995. The text of the Egyptian State Council Law stipulates that no member of the Council of State may be married to a foreign woman, which the Egyptian Supreme Constitutional Court considered contrary to the agreements signed by Egypt, deeming this part of the law repealed (Article 73 of the State Council Law 47 of 1972) 2 .

The Constitutional Court of Kuwait also has the authority of interpreting constitutional text through requests submitted to it by either the government or National Assembly. The Court cannot protect fundamental rights and liberties through these interpretative decisions, as most of these decisions are related to the limits of legislative and executive authorities and their relations to each other.

Under the Court's jurisdiction also falls the competence to examine electoral appeals associated with the National Assembly. These are, in general terms, mostly related to the electoral process, but the Court may, through these appeals, adjudicate an important constitutional issue as it has done in the case of the hijab of MP women in 2009.

1 The Emir/Prince concludes treaties by decree and transmits them immediately to the National Assembly with the appropriate statement. A treaty has the force of law after it is signed, ratified, and published in the Official Gazette.

2 Naguib Bouzid, Supervision of Constitutionality of International Treaties, MA Thesis, Mansoura: House of Law and Thought, 2010. 
The fundamental role played by the Constitutional Court lies in protection of fundamental liberties when hearing the appeals related to the constitutionality of laws and regulations. The Constitutional Court does not have the right to issue direct orders to various authorities, but it can, by examining the legislation submitted by the aggrieved party, repeal or invalidate a law or regulation that violates fundamental liberties prescribed by the Constitution.

Individuals may bring cases before the Constitutional Court through number of ways and procedures. When doubts about the constitutionality of a decisive law or regulations are planted in an ongoing court case, the ordinary court (e.g. criminal court, administrative or labor court) that has the case before it, shall suspend adjudicating this case until the Constitutional Court decides on the constitutionality of the law or a regulation related to the case. In this first situation, there are two ways for the case to be filed to the Constitutional Court, either through a referral from the trial court or through a referral by the Appeals Review Committee.

We will address the different ways of bringing the constitutional case before the Constitutional Court.

\subsection{The body concerned with hearing the appeal of unconstitutionality}

Constitutional motion belongs to the group of corporeal lawsuits in which the dispute is directed to challenge legislative texts in order to reach a ruling on unconstitutionality, or to render a decision of its constitutionality and being acquitted of all defects and appeals ${ }^{3}$.

The constitutional legislator has identified one body that oversees the process of reviewing laws, decree-laws and regulations that contain a suspicion of unconstitutionality. He called it the "judicial authority" The constitutional legislator has selected the centralized judicial review. The law on the establishment of the Constitutional Court was passed in 1973. It contained regulations that may be deemed contrary to the desire of the constitutional legislator in more than one aspect. The law constituted this body as a court, its members being a group of judges ${ }^{4}$, while the constitu-

3 Adel Omar Sharif, "Constitutional judiciary." Constitutional Judiciary in Egypt, 1988: 459 and the following pages; Sha'ban Ahmed Ramadan, Controls and Effects of the control over the Constitutionality of Laws: A Comparative Study. PhD Thesis, Dar Al-Nahdah Al Arabiya: Assiut Faculty of Law, 2000: 565.

4 There were draft laws closer to the constitutional orientation, one of these draft laws stipulated the following: "The Constitutional Court shall be composed by a decree 
tional legislator had a clear desire to have members from the judiciary as well as others representing the government and the National Assembly. The law also deprived individuals of direct appeal before that court and granted individuals the right to resort to collateral plea before ordinary courts ${ }^{5}$. In contrast, the law granted both government and National Assembly the right to appeal directly to the Constitutional Court, and also granted the ordinary courts, during the hearing of a case, to refer to the Court in case of suspicion of unconstitutionality.

\subsection{Referral by ordinary trial courts}

Referral by ordinary courts takes place when the case is at bar before an ordinary court to adjudicate thereon, but the judge believes, on his own initiative or on the basis of a plea submitted by litigants, that the law governing the case contains an unconstitutional suspicion of violating the provisions of the Constitution or its principles. He then decides to suspend the hearing of the case and refers it to the Constitutional Court to decide on the constitutionality of the legislation or regulation in question. Accordingly, the constitutional motion shall be registered and heard before Constitutional Court and it shall be obliged to adjudicate the constitutionality of the law or regulation. In case the Constitutional Court declares it unconstitutional, then the case, subject matter of the first lawsuit, shall be expired as a result of this decision according to the degree of text revocation associated with the motion.

The plea of unconstitutionality is not one of the formal or subjective pleas; it is aimed at sublimity of constitutional rules and therefore may be filed as it is and before any court ${ }^{6}$.

as follows: three advisers chosen by the Judicial Council by secret ballot. Their choice may be by delegation and the senior of them shall be the President of the Court as well as two lawmen or Islamic jurists from the Kuwaiti universities elected by the Council of Ministers and two members of the National Assembly with high qualification chosen by the National Assembly and the Head of the Public Law Department of Kuwait University ex officio..." see Othman Abdul Malik, "Constitutional Organization for the Judicial Supervision of the Work of Administration in Kuwait and Attempts to put it into Practice.” Journal of Law, 10.2.

5 Othman Abdul Malik Al-Saleh, The Constitutional System and Political Institutions in Kuwait, Part I. Kuwait: Dar al-Ketub, 2003: 661.

6 Case 23 of the $14^{\text {th }}$ Constitutional hearing of February 12, 1994 C6, Ruling 18: 174; Munir Abdul Majid, The Origins of Judicial Control over the Constitutionality of Laws and Regulations. Al Maarif Establishment, 2001: 14. 
As long as the trial court has the power to refer the constitutional motion on its own initiative, this means that the plea of unconstitutionality is a part of public order ${ }^{7}$.

Article 4 (Para, B) of the Constitutional Court Establishment Law provides that,

"disputes shall be referred to the Constitutional Court in one of the following two ways: (b) If one of the courts, in the course of considering a case, whether by itself or on the basis of grounded plea submitted by one of the parties to the dispute, holds that adjudicating the case is based on constitutionality of a law, a decree-law or regulation, then it shall suspend considering the case and shall refer the matter to the Constitutional Court to decide thereon..."

This is a right of all courts of all degrees, whether before Court of First Instance, Court of Appeal or Court of Cassation ${ }^{8}$.

\subsection{Appeal before the Appeals Review Committee}

The Constitutional Court Establishment Law of 1973 has established a committee emanating from the Constitutional Court called the Appeals Review Committee. This committee consists of three members of the Constitutional Court and is responsible for examining the seriousness of the appeals filed before it. In this way, one of the parties to the dispute before Trial Court has to sustain a plea on the grounds of unconstitutionality of a law, decree-law, or regulation. The Court then rejects such a plea, and the appellant impugns the decision of the trial court rejecting the plea before the Appeals Review Committee. The Appeals Review Committee shall examine the seriousness of the plea only, without examining other elements related to the case. If the Committee decides that the plea is serious, the case shall be registered before the Constitutional Court to examine the constitutionality of the law, decree-law, or regulation. If the Committee decides that the plea is not serious, it shall issue its decision of refusal and return the case to trial court for adjudication with the constitutional presumption in favor of the legislation governing the subject matter of the dispute.

7 Yousri Al-Assar, The Term of Interest in the Case of Revocation and in the Constitutional Motion, 1994: 49.

8 Turki Sattam Al-Mutairi, Procedural Pleas in the Constitutional Motion, 2012: 230. 
The Appeals Review Committee's final decisions cannot be appealed, not even by the Constitutional Court ${ }^{9}$. It is a judicial committee emanated from the Constitutional Court that examines the seriousness of pleas that have already been rejected by the trial court. This is a mechanism created by the legislator to assist the Court in settling appeals submitted to the Constitutional Court ${ }^{10}$.

The Appeals Review Committee is an associate apparatus of the Constitutional Court, not a court of appeal in relation to trial court. It is formed of members of the Constitutional Court itself, organized by the Constitutional Court Rules in Article 8, which states that,

"the Appeals Review Committee shall be constituted chaired by the President of the Court and membership of Court's senior advisers and shall follow proceedings prescribed before the Constitutional Court."

This Committee, despite the nature of its formation, differs from the Constitutional Court in terms of nature, jurisdiction and formation. The Constitution did not refer to the formation of the Committee, but its fundamentals are found in the Constitutional Court Establishment Law ${ }^{11}$.

Sub-appeal is a right entitled to any of the litigants with respect to substantive case, before a court, to raise the constitutional issue in this case to plea unconstitutionality of legislation which shall be applied in the case brought before the court.

This has been the only means for individuals since promulgation of the Constitutional Court Establishment Law until 2014 when a provision allowing individuals to appeal directly to the Constitutional Court was added.

The Constitutional Court Establishment Law in Article 4 paragraph B stipulates that,

"...the concerned parties may appeal the decision of plea non-seriousness before the Appeals Review Committee in the Constitutional Court within one month of issuance of the said decision. The Committee shall promptly adjudicate this appeal" 12 .

In case the trial court holds that seriousness of plea is lacking, the appeal against this decision shall be before the before-mentioned Appeals Review

9 Muhammad Al-Muqati, A Study in the approaches of Kuwaiti Constitutional Judiciary. Kuwait: Kuwait University Press, 1999: 47.

10 Al-Muqati, Kuwaiti Constitutional Judiciary: 50.

11 Al-Muqati, Kuwaiti Constitutional Judiciary: 57.

12 Al-Mutairi, Procedural Pleas: 384. 
Committee in the Constitutional Court within one month. During this period, the appeal notice shall be submitted to the Committee in addition to a notification to be served to litigants during this period ${ }^{13}$.

\subsection{Direct complaint before the Constitutional Court}

In 2014, a law on direct complaint before the Constitutional Court was passed, known as Law 109 of 2014 On Allowance of Direct Appeal before the Constitutional Court. Thus, it became possible for any person harmed by any legislation that restricts any fundamental liberties to resort to the Constitutional Court to demand the repeal of a law, a decree-law or regulation containing a constitutional violation, even if the direct resort to the Constitutional Court is very expensive and a burden on the appellant more than the said traditional method.

The appellant here shall obtain the signature of three lawyers registered with the Constitutional Court in addition to the payment of a guarantee amount of 5,000 Kuwaiti dinars. The Court shall examine the complaint in the chamber and shall examine whether it is serious or not, in addition to the formal requirements of the complaint, and the element of jurisdiction. If the Court holds that the complaint meets all these requirements, the appeal shall be accepted and registered and the hearing shall be scheduled to hear the complaint.

The terms that must be satisfied for the acceptance of the motion are general conditions, namely the existence of interest and capacity. The interest means the interest taken by the plaintiff as a result of his requests for the subsequent review of texts by the Constitutional Court. The requirement of direct personal interest is of importance and is one of the conditions for accepting a constitutional motion.

Existence of interest is necessary for motion acceptance. No motion without interest. The nature of this interest is to be interrelated with the interest existing in the substantive case and that the ruling on the constitutional issue would affect the requests of the complaint.

The capacity merges with the interest whenever the person has an interest, only then he enjoys capacity. It is not sufficient that the text in question is contrary to the Constitution, rather its application to the plaintiff must represent a violation of one of the rights guaranteed by the Constitution in a way that is directly prejudicial to plaintiff. The

13 Al-Mutairi, Procedural Pleas: 385. 
constitutional matter shall not be considered separately if the appealed text has not been originally applied to the plaintiff, if he is not governed by its provisions, has benefited from its advantages, or if the violation of the rights he alleges is not related to him. So, the nullification of the legislative text will not bring to the plaintiff any benefit other than being null and void.

Requirement of direct personal interest is determined by two elements:

1. The plaintiff shall provide evidence that real or other economic damage has been inflicted upon him, whether or not he is at risk of such damage or if it is already occurred. The alleged harm must be direct, and separate from the mere violation of the appealed constitutional text, and independent with its elements.

2. Such harm shall be a result of the appealed text, not intentional, fraudulent, impersonated or presumptive harm.

The interest is an original condition in the sense that the plaintiff must have a personal interest directly at the time of filing his constitutional motion and interest will continue until the motion is adjudicated. Accordingly, in case of a criminal lawsuit that ends with acquittal of the accused by virtue of a final court ruling before decision is rendered by the Constitutional Court, the interest shall be void and the Court shall decide to remand the motion.

The court's examination of interest requirement for individuals is confined to the sub-appeals cases and referral by a trial court and direct appeal, since the amendment by the Law on Direct Appeal in 2014.

The court accepted the potential interest in addition to moral interest in the constitutional motion.

The capacity requirement must be fulfilled so that a person who has the capacity to bring it up must claim a right or legal status for himself ${ }^{14}$. Some argue that the element of capacity is merely a description of the interest and that they unite with each other, but the most prevailing opinion in the constitutional judiciary holds that the capacity is different from interest. Such distinction becomes self-evident when the stakeholder is incapacitated, so the motion is initiated by a person who has the capacity

14 Ahmed Hindi, Origins of Civil and Commercial Procedure Law. New University House, 2002: 311. 
to represent this person such as his/her guardian or custodian, hence, the capacity is a requirement to initiate the constitutional motion ${ }^{15}$.

The Kuwaiti Constitutional Court decided that there must be a correlation between the constitutional motion and the substantive case for which the plea of unconstitutionality is raised ${ }^{16}$. The Court holds that,

"the trial court does not refer the matter to the Constitutional Court unless adjudicating the dispute is subject to adjudicating the constitutionality of a law, decree-law or regulation ..., Adjudicating the constitutional issue is necessary for possibility of substantive adjudication of the dispute..."17.

It is not sufficient that the appealed text is contrary to the Constitution, but its application to the plaintiff has violated one of the rights guaranteed by the Constitution in a way that is directly prejudicial to the plaintiff ${ }^{18}$. The constitutional matter shall not be considered separately. If the appealed text originally has not been applied to the plaintiff, if he/she is not governed by its provisions, has benefited from its advantages or if violation of the rights he alleges is not related to him, hence, the invalidity of the legislative text will not bring the plaintiff any benefit by which his legal status may change after the decision in the constitutional case from what it was upon when the appeal was submitted.

\subsection{Direct appeal by government and National Assembly}

The law on the Constitutional Court's establishment of 1973 has granted both government and National Assembly the right to lodge a constitutional complaint directly before the Constitutional Court, without requiring the existence of a substantive case before a judicial body, as stipulated in Article 4 of the Constitutional Court Establishment Law "disputes are submitted to the Constitutional Court in accordance with one of the following two ways: A. At the request of the National Assembly or the Council of Ministers ...”.

15 Salah Al-Din Fawzi, The Constitutional Motion. Cairo: Dar al-Nahda al-Arabiya, 1998: 128.

16 Yousri Al-Assar, The Role of Practical Considerations in Constitutional Judiciary. Cairo: Dar Al-Nahda Al-Arabiya, 1995: 85.

17 A decision rendered on Appeal No. 25/1085, see Dhuheban Al-Ajmi, Constitutional Court Rulings from 1973 to 1995: 148.

18 Case 25 of $6^{\text {th }}$ Constitutional, Group 5: 122. 
In the event that the National Assembly desires to submit the request, the majority must approve ${ }^{19}$. Similarly, the government must take its decisions with the approval of the majority of the Council of Ministers (the Cabinet) in accordance with provisions of Article 128 of the Constitution $^{20}$.

Jurisprudence has been criticizing this method as favoring accessibility by the government and the National Assembly, in spite of them having tools to amend various legislations through legal channels, without a need to resort to the Constitutional Court, while individuals were denied the right to direct resort while they have to be prioritized in this matter ${ }^{21}$.

\subsection{Binding force of the decision rendered by Constitutional Court}

Binding force of the constitutional decision refers to that if a decision is rendered, it shall have a binding force on rights adjudicated, it has to be respected and followed even before other courts, in order to prevent dispute with respect to the of adjudicated matter again.

As for the binding force of the decision rendered by the Constitutional Court, many questions are posed, e.g. does the decision of unconstitutionality mean that the law is null and void, or does it merely giving an assignment to the trial court judge to neglect the law and refrain from applying it to the dispute before him/her only among the same litigants?

In Article 173 of the Constitution the constitutional legislator had settled the dispute in this matter, where it decided to consider the appealed text null and void as it possesses a general and absolute binding force, binding to all, including rest of the ordinary courts 22 .

19 Othman Abdul Malik Al-Saleh, Judicial censorship before the Constitutional Court of Kuwait: 46.

20 Article 128 of the Constitution: "Deliberations of the Council of Ministers are secret. Resolutions are passed only when the majority of its members are present and with the approval of the majority of those present. In case of an equal division of votes, that side prevails on which the Prime Minister has voted."

21 Abdul Malik Al-Saleh, Judicial censorship: 83; Ramzi Al-Shaer. The General Theory of Constitutional Law. Kuwait: Kuwait University Press, 1972: 653.

22 "The law shall specify the judicial authority which is competent to adjudicate disputes relating to the constitutionality of laws and regulations, and shall specify its powers and procedures, and in the event that the said body decides unconstitutionality of a law or regulation, it shall be null and void. The law guarantees the right of both the government and the concerned parties to appeal to that body in terms of the constitutionality of laws and regulations." 
The problem may not arise in the case a law, decree - law or regulation is declared unconstitutional, where the text shall be null and void as has been indicated. The dispute arises when the court issues its ruling to dismiss the appeal or the case - which is more than a probability. If the case is rejected for formal reasons, such as the time requirement default, the requirement of interest or the absence of a lawyer signature on the statement of claim, the cases do not cause significant problems. The binding force in these cases is relative in the sense that the binding force applies only on the parties of the litigation. These cases shall not prevent reconsideration of the appeal before the Court in the event that the conditions and dates are met.

However, the problem arises if the appeal is rejected in terms of merits. In other words, when the court confirms constitutionality of the appealed text, a dispute arises concerning the binding force of these decisions. Some argued that in this case the binding force shall be relative according to the parties in dispute, in the sense that this would not preclude further review of constitutionality of the same text before the Court once again ${ }^{23}$.

The Supreme Constitutional Court of Egypt rejected this approach in one of its rulings and held that in this case the ruling binding force is relative and limited to the parties to the dispute, in this regard. The Court stated that,

"this ruling does not affect the legislation that has been challenged as unconstitutional. The legislation remains valid after the decision is rendered. The said decision only holds relative binding force between the parties to the dispute, so the appeal of unconstitutionality may be revoked as per this valid legislation again ..." 24 .

However, some scholars opposed the judicial approach as stated in the previous ruling on the grounds that the legal texts governing the actions of the Supreme Constitutional Court did not differentiate between the decisions of unconstitutionality and the rulings issued to dismiss the lawsuit ${ }^{25}$. This approach is supported in a later ruling of the Supreme Constitutional Court itself where it decided the following:

23 Mohamed Seid Zahran, "Control over the Constitutionality of Laws in Italy." Journal of Government Issues Management 14.1, January-March 1970: 142.

24 Decision of the Supreme Constitutional Court of 11 December 1976.

25 Amr Hassabo, Implementation of the Decisions of unconstitutional legislative texts, Cairo: Dar al-Nahda, 2002: 29. 
"The binding force of the rulings issued by this court in constitutional matters are not confined to the adversaries of the constitutional motion, but extend to the state with all its branches and organizations, and include all the people subject to a safe application of the constitution and abidance with the peremptory norms." 26

Jurisprudence supports this approach of the Supreme Constitutional Court, where jurisprudence believes that binding force of decisions is alike, both in terms of the substantive acceptance or rejection ${ }^{27}$.

3. Positive constitutional decisions with respect to the protection of fundamental liberties

Under this topic, we will discuss the constitutional decisions positively addressed by the Constitutional Court in relation to the protection of fundamental liberties. There are numerous decisions, but we will have to select among them:

\subsection{Decisions of the Constitutional Court relating to the application of Islamic sharia}

The Court has dealt with several decisions regarding the mechanism of applying the provision derived from Islamic sharia. It has answered several questions about whether sharia is self-executing or whether it needs to be mediated by the legislator to put into it a legislative form in order to be applied. We will select some decisions concerning attitude of the Constitutional Court towards Islamic sharia.

26 Decision in Case No. 22 of $18^{\text {th }}$ Constitutional, Session of 30 November 1996, Group, Part VI: 76.

27 See Ramzi Taha Al-Sha'er, The General Theory of Constitutional Law, Cairo: Dar al-Nahda al-Arabiya, $3^{\text {rd }}$ edition, 1983: 608; Taima Al-Jarf, Constitutional Decision, Comparative Study in Constitutional Control. Cairo: Dar al-Nahda, 1993: 289. 


\subsubsection{The decision of the Constitutional Court regarding hijab of two members of the Kuwaiti National Assembly}

Kuwaiti women had been deprived of the right to stand for election since the establishment of the Constitution in 1962 until 2005, when the Law on Granting of Women's Political Rights was promulgated, and a special provision was added to women alone. Law 17 of 2005 amending the Law on the Election of the Members of the National Assembly (Law 35 of 1962) was issued amending the article through adding the following statement: "women are required to adhere to the rules and provisions adopted in Islamic law when running for election and electing".

In fact, the terms used in the legislation are loose and vague, what does this phrase mean? Are only women obliged to abide by the rules and provisions adopted in Islamic law? Are there rules for men's dress and appearance in Islamic law? Does the provision mean formal or behavioral obligation? The legal assessment element in the mentioned article is not clear, and therefore it is difficult for women to abide to something because of ambiguous texts in the previous article.

It is noted that the text did not address the dress and appearance of women. When the elections of the National Assembly were held in 2009, four women won in various constituencies, but there were two members, namely Aseel al-Awadhi and Rola Dashti, who did not wear the hijab. Thus, a voter challenged the validity of their membership for violating Article 1 of the Electoral Law. The Court dismissed the appeal and we summarize what was discussed in this case as follows ${ }^{28}$ :

The facts are summarized that the plaintiff challenged the validity of the 2009 National Assembly elections. In his lawsuit, he claimed invalidity of the candidacy of Mrs. Aseel Al-Awadhi and Rola Dashti, as the first and second appellees violate the Electoral Law of National Assembly Members 35 of 1962 as amended by Law 17 of 2005 . The first Article required the candidate women to abide by the rules and provisions of Islamic law; these rules and provisions stipulates to wear the hijab, to bring down over themselves (part) of their outer garments, to hide the adornment from men, and that only the face and hands can be discovered since the woman's body is' awrah (private part). This ruling is established as per the Holy Quran, Prophetic sunna and agreement of the Imams.

Since the first and second defendants do not wear the hijab and have won parliamentary seats by election, this is contrary to the said article of

28 Decision of the Constitutional Court 20 of 2009 issued on 28 October 2009. 
the Electoral Law, according to the plaintiff's statement and therefore the Court must declare invalidity of their membership for violating conditions of candidacy.

In its interpretation of Article 1 of the Electoral Law, the Constitutional Court stated that this Article has been drafted in a collective form, without specifying holistic cross-cutting definition to clarify the meaning. It used the minutes of National Assembly to determine the meaning of the text, but was unable to determine the meaning, thus it decided that,

"in the field of figuring out the denotations from legislative texts, if the text is loaded with more than one meaning, it must be interpreted according to the meaning that makes it more compatible with higher legislation, and as reflects its correct meaning, avoids contradiction, even if this meaning is less apparent. The interpretation of this text shall be within the framework of governing principles and fundamentals contained in the Constitution in letter and spirit".

The Court highlighted that Islamic law is not the sole source of legislation $^{29}$. The Constitution does not prohibit legislators from adopting other sources according to the public interest. The decision also indicated that the Constitution also "guarantees personal freedom and made freedom of faith unrestricted, for it is within the scope of belief or the inner thoughts which shall be ordained by Allah, but no distinction between people in rights and duties or because of religion or sex."

Moreover, the Court stipulated that:

"Islamic law rulings do not have the binding force like the legal rules unless the legislator intervenes and codifies the Islamic principles. It does not have the power of self and direct execution, but it must be molded in specific legislative texts and a specific legislative content that can be adhered to by both governed persons and those who execute and apply thereof. Accordingly, it is not possible to equalize it to substantive texts. The substantive text is self-executing in its substantive rulings, and therefore the text referred to cannot be described as containing a specific substantive rule. This text, in accordance with its content, is guiding provisions, which are provided for control and guidance, not intended to be binding and obligatory. This is reflected in the explanatory note of the law in this regard, it is inconceivable that the will of the legislator has been directed - within the framework of this existing text - to leave those responsible for implementation and execu-

29 The Constitution of Kuwait deviates from the terminology of the Egyptian Constitution, which stipulates Islamic law as "the" source of legislation. 
tion thereof to investigate such undetermined rules and provisions, which may lead to confusion and contradiction between these rules and provisions according to the different views of jurisprudence".

The Court interpreted Article 17 of the Electoral Law in accordance with the Constitution, specifically Article 2, Articles of rights and liberties, such as personal freedom, freedom of belief, through reconciling them. It tried to reconcile between the view that sharia was a source of legislation and freedom of belief. In the end, the Court rejected the appeal and validated their membership.

\subsubsection{The ruling of the Constitutional Court regarding the right of a woman to travel and extract a passport without the consent of her husband $d^{30}$}

In the case to be discussed, the plaintiff filed her case before the Supreme Court and specifically before the Civil Commercial Circuit. In this case there are four adversaries; these are the plaintiff's husband, the two representatives of Ministry of Interior and Health in their personal capacity, and the Director General of the Public Authority for Civil Information in his personal capacity.

The first defendant, namely the husband refrained from handing over the passport to the plaintiff and also refrained from handing over identity documents to her children. In her case, she requested to oblige her husband, the first defendant to hand over all the required papers. In case of his refusal, she requested to be allowed to extract these identity documents as her passport, her children's passport and the rest of the papers from the Ministry of Interior, the Ministry of Health and the Public Authority for Civil Information.

During the proceedings, the Trial Court held that the legal provision of Article 15 of Law 11 of 1962 Regarding Passports which stipulates that a wife may not be granted an independent passport without the consent of husband, is vitiated by the constitutional suspicion of violating Articles 29. 30 and 31 of the Kuwaiti Constitution, and therefore the court decided to suspend the case until constitutional issue is resolved.

The Constitutional Court then examined the current appeal. The first defendant submitted his statement of claim requesting to dismiss the lawsuit and confirmed that there was no conflict between the challenged

30 Ruling of the Constitutional Court in Case No. 56 of 2008 "Constitutional" issued in the hearing of 20 October 2009. 
article and the Constitution. He also stated that the appealed text complied with the provisions of Islamic sharia originally considered by the Constitution as a main source of legislation.

After the Court heard the requests and pleadings, it ruled that:

"every Kuwaiti - male or female - has the right to extract and hold the passport, since this right is not only a title to his belonging to the State of Kuwait, the source of our proud and pride ... rather, it is also a manifestation of personal freedom that the Kuwaiti Constitution has made a natural right to safeguard and protect though its principles."

It is stipulated in Article 30 that "personal liberty is guaranteed", Article 31 states that:

"No person shall be arrested, detained, searched, or compelled to reside in a specified place, nor shall the residence of any person or his liberty to choose his place of residence or his liberty of movement be restricted, except in accordance with the provisions of the law..."

The Court also stated in its ruling that Islam has already preceded the positive constitutions in recognizing the right of movement for every individual as he/she wishes. Islamic law has made freedom of movement the general rule and restricting it is an exception, which is only a necessity that shall be valued according to the circumstances and in favor of the public interest and Islamic ruling. The ruling also states that Islamic law does not prevent women from traveling as long as they are with a mahram ${ }^{31}$, a husband or a trusted companion, or - according to the view some scholars have adopted - if women committed themselves to respect the limits of legality and ethics of Islam ${ }^{32}$.

The Court also stated that:

"personal liberty is the basis of other public liberties and an inherent right of the individual; it represents self-independence of each individual. The will to choose represents a scope for personal liberty without which the individual's personality is not integrated; among its foundations is the freedom of movement and the right to travel branched out of $i$. It is one of the categories of

31 In Islam, mahram means "unmarriageable kin with whom marriage or sexual intercourse would be considered unlawful".

32 Asma Al-Sairafi. Effectiveness and Effect of Amendment of Article 2 of the Kuwaiti Constitution. Comparative Study with the Egytian Constitution of 1971. MA Thesis, Kuwait University. 
public liberties that cannot be restricted without cause, fight against them without justification, or restrict them without necessity."

The Court then explained that the Kuwaiti Constitution had entrusted the legislature to assess this requirement, but it was not permissible for the legislature to place restrictions on this right to the extent that the limitation comes close to revoking, derogating, or nullifying this right. The Court also stated as important principle that "the legislator must not violate the balance between the provisions of the Constitution and his rules which are integrated within one framework".

Finally, the decision drew from the said principle in the area of legislating laws and the necessity of respecting the balance between provisions of the Constitution and the enacted legislations. It stressed that rendering a decision of unconstitutionality of the previous text

"does not violate the right of husband according to the general rules to prevent his wife from traveling when well-established evidence is provided that the use of this right shall harm her and her family. Revocation of the text also does not prejudice the right of the legislator to regulate the extract and renewal of the wife's passport and withdraw thereof, striking a parallel between the freedom of movement... and what is stipulated by Article 9 of the Constitution guarantees the reconciliation of women duties towards the family ... and being of equal rights with men in accordance with Article 29 of the Constitution, and without prejudice to the provisions of the lofty Islamic sharia and the provisions of Article 2 of the Constitution that states that "The religion of the State is Islam, and the Islamic sharia shall be a main source of legislation"”.

\subsection{The Court's position on legislation affecting the right to equality}

The courts in Kuwait have had several opportunities to interpret the equality guarantee, where the court has recognized disparate impact on women as violation of equality.

\subsubsection{The Court's ruling regarding the equality of women in the housing} allowance with men

In Article 8 of Cabinet decree 14 for the year 1977, regarding the salaries and degrees of judges, prosecutors, and the employees of the Fatwa and 
Legislation department, which was modified by Cabinet degree 124 for the year 1992, states:

"Judges, members of the prosecution department, and members in 'Fatwa and Legislation' shall be given an appropriate domicile commensurate with their position, and further order shall be issued by the Cabinet."

On the basis of this article, the cabinet issued Order 142/1992, modified by Orders 1162/1992 and 734/seventh/1992, which state:

"Judges, members of the prosecution department, and members of 'Fatwa and Legislation' shall have the option between the allocation of government housing or receive a housing allowance of: 200 for singles, 300 for married."

Article 3 of this order states that "the allocation of government housing and receiving a housing allowance shall not be provided for the following categories; $1-\ldots 2-\ldots . . . .4-. .5$ - females unless if married."

As a result, Hend Al-Bin Ali, a single woman who is a member of Fatwa and Legislation department, sued all the following: 1) the President of Fatwa and legislation in his capacity; 2) Minister of the State for Cabinet Affairs in his capacity; 3 ) the Prime Minister in his capacity, for violating the Constitution. In this case, the single male member was provided with 200 K.D, but not the single female, and Al-Bin Ali alleged that this unjust treatment based on gender without any legal justification is a violation of the Constitution, especially Articles " 733 , $8^{34}, 18,20^{35}, 22^{36}, 29,41^{37}$, 50, and $163^{38}$." She filed Case 5/2008 before the Constitutional Court of Kuwait demanding to be paid the same amount as her male fellows and

33 Justice, Liberty, and Equality are the pillars of society; cooperation and mutual help are the firmest bonds between citizens.

34 The State safeguards the pillars of society and ensures security, tranquility, and equal opportunities for citizens.

35 The national economy shall be based on social justice. It is founded on fair co-operation between public and private activities. Its aim shall be economic development, increase of productivity, improvement of the standard of living, and achievement of prosperity for citizens, all within the limits of the law.

36 Relations between employers and employees and between landlords and tenants shall be regulated by law on economic principles, due regard being given to the rules of social justice.

37 (1) Every Kuwaiti has the right to work and to choose the type of his work.

(2) Work is a duty of every citizen necessitated by personal dignity and public good. The State shall endeavor to make it available to citizens and to make its terms equitable.

38 In administering justice, judges are not subject to any authority. No interference whatsoever is allowed with the conduct of justice. Law guarantees the indepen- 
to disburse any financial differences by alleging the unconstitutionality of the fifth part of Article 3 of Cabinet Order 142/1992, modified by Order 743/1994. She claimed that it contains discriminatory and differential treatment for males and females in receiving housing allowances, which constitutes a violation of the equality principle of the Constitution.

In this case, the Constitutional Court began its examination by stating that the appellant merely asked that the constitutionality of part five of the said order be examined; therefore, the Court could not take any further action beyond the request. It stated:

"The appellant had alleged the unconstitutionality of part five based on its denial to provide a single female member with the housing allowance that is given to her male counterpart, which constitutes a breach of the equality principle since the Constitution has confirmed and assured the necessity of respecting the equality principle in many of its articles, such as Article 29, which explicitly prohibits any distinction based on gender, origin, language, or religion, and is a complement to Article 7 that assures that justice, freedom, and equality are pillars of society, as well as Article 8, which states that 'The State safeguards the pillars of society and ensures security, tranquility, and equal opportunities for citizens.' Not surprisingly, the content of Article 29 is a general provision directed to all the government's branches and authorities, committed by the legislative branch in its enactment, as well as by the executive branch in its regulations and regulatory decisions; the judicial branch is committed by it in when it handles the organization of judicial affairs and when it decides the cases of the people. Equality in its essence means to equalize and to treat similarly situated people as the same, and to differentiate between unlike people or categories as different in their legal situations. Therefore, equality before the law means that all people are equal before the law without any distinction or discrimination, since the rights and privileges, which are provided by the law and enjoyed by the targeted people who are covered uniformly by its provision, are ensured by the protection of the law to the same degree. People are compelled by legal obligations and requirements equally and without any distinction, and when the government classifies a group to whom an order or legislation applies or upon whom a benefit is conferred, the classification must be reasonable and must rely upon the fact that the difference has a just and considerable relation to the legislation's goals.

dence of the judiciary and states the guarantees and provisions relating to judges and the conditions of their irrevocability. 
Judges, members of the prosecution department, and members of 'Fatwa and Legislation' are among the Cabinet members who are given an option between an allocation of governmental housing or receiving a housing allowance in Order 1162/1992 and Order 734/seventh/ 1994, Article 2, and yet in part five of Article 3, it clearly states that women are not eligible for this privilege except if married, despite the fact that their male colleagues enjoy this privilege. As a result, the challenged Cabinet order wrongfully differentiated between similarly situated persons without any legal reason or purpose, which constitutes an arbitrary probibited discrimination that violates the principle of equality assured by Article 29 of the Constitution, and based upon the foregoing, the court has held the unconstitutionally of part five of Article 3 in Cabinet Order 142/1992 about the governmental housing for judges, members of the prosecution department and members of 'Fatwa and Legislation', which was modified by Cabinet Order 734/ seventh/ 1994."

The Constitutional Court has not explicitly acknowledged or chosen between models of equality when deciding equality cases, except in pronouncing that persons in similar circumstances be treated alike. From the language of the decision, it would seem that the Court has adapted the formal model; nonetheless, the holding in this decision is compatible with both formal and substantive models because the regulation that was struck down violated both models. It is unclear which one was intended, and hence it leaves the final choice open.

The Court did not examine whether it would follow a similar interpretation even if the outcome of identical treatment were severely unjust for a specific group. Thus, this formal interpretation has not answered the question of whether the application of equality should fulfill the requirements of justice.

Moreover, the Constitutional Court has not developed a theory of scrutiny that should be used regarding the governmental classification cases. Thus, the Court's method in deciding who is alike and who is different is ambiguous, and it is unclear whether it uses the levels of scrutiny or the Canadian scale of scrutiny. As a result, when any legislation classifies persons, how do we ensure that these classifications are products of rational analysis and not automatic applications of traditional assumptions about the appropriate role for specific groups in society? 


\subsubsection{Ruling on depriving women of housing allowance because of the husband's benefit by housing care}

In another case that was decided by the Constitutional Court in Kuwait, the appellant (Suaad Al-Bustan) filed Complaint 18/2006 (Constitutional) against the government and sued all of the following: 1) the Manager of Kuwait University in his capacity; 2) the Chairman of the Board of Civil Service in his capacity; and 3) the Minister of Higher Education in his capacity as the Head of Kuwait University, alleging that the refusal to pay her the housing allowance violates her constitutional right of equality.

The appellant was a lecturer in the linguistics department at Kuwait University. She was initially paid the housing allowance, but the university stopped the payment, contending that her husband at the time had government housing.

The regulation of residential care that was issued by the Minister of Higher Education in Order 30/2001 stipulated in part (E) of Article 2 that in order to receive the housing allowance, either husband or wife should not enjoy residential care of any kind by Kuwait University or by any other entity. However, the appellant's husband had a governmental house that was occupied by him and his first wife and their daughters, but not by the appellant, and so she brought this action claiming that the fact that her husband enjoys residential care should not justify preventing her from receiving the housing allowance, since she does not enjoy the residential care. The housing allowance that she was supposed to be receiving was the result of her prestigious position as a teacher at the university. Because most women employees do not receive this housing allowance, and because she was receiving it as a privilege in this unique position, she alleged that the university could not deprive her of any employment privilege based on reasons that were not related to the employment. As a result, she asked the court to decide the unconstitutionality of part (E) in Article 2 because it deprived her of her right to housing merely based on her husband's enjoyment of housing services, which constitutes unconstitutional discrimination and violation of the equality principle and Articles 7, 8, and 29.

The Constitutional Court in the last part of its holding stated:

"The article's requirement that each of husband or wife should not be covered by the residential care as a condition to receive the housing".

However, part (E) of Article 2 does not prevent the wife from receiving the allowance, even if her husband enjoys the residential care, if it is shown that she does not benefit from her husband's house. As a result, this law 
was wrongfully applied to the appellant, and this fact does not render the article to be unconstitutional because it serves governmental interest in maintaining the structures of the family and strengthening its ties and unity. As a result, there is no legitimate interest on the appellant's side to decide the constitutionality of the article since her allegation and the damages were based on an incorrect application and interpretation of the article by the department; thus, it removes this issue from the scope of the constitutionality claim, and the claim is denied."

The Court in this case has rightfully applied the substantive model in its interpretation by moving beyond the language of the regulation. The court has found that this regulation is facially neutral because it applies to both husbands and wives, but it found that this regulation has a disparate impact on women. The impact is disparate because the practice of polygamy means that only wives will lose their housing allowance when their husband's housing is shared with a different wife.

\section{Conclusion}

The Constitutional Court has played a pivotal role in protecting the fundamental liberties, although it believed that it could have a greater role in that regard. However, the Court sometimes relied on conformities and on maneuvers at other times. This does not preclude acknowledgement that it had recognized several human rights principles and contributed to the establishment of constitutional principles in some areas, and participated in the consolidation of constitutional principles in some fields such as principles of equality and freedom of litigation. Other institutions also protect liberties, albeit slowly, like the Human Rights Committees of the National Assembly, and the Committee of petitions and complaints in the National Assembly. However, the fundamental role to review legislation must be played by the Constitutional Court, especially since the court cannot direct the government to carry out a specific act or abstain from a certain conduct. The role of the Constitutional Court lies only in the orbit of legality and examination of legislations that violate the Constitution, although it possesses some sort of directing capacity when interpreting constitutional texts through requests for interpretation by the government or National Assembly. However, these requests often focus on the relationship of the legislature with the government and their mutual means.

In our point of view, a legislative intervention must first be made in order to allow individuals to resort directly to a court without overcharg- 
ing individuals with excessive fees, which is contrary to the inherent right to litigation. Also, the Constitutional Court must grant all the means to direct the authority to act or refrain from acting if such acts were not based only on a legislative basis, but comprise a clear constitutional violation or violation of the spirit of Constitution. 
